\title{
MODIFICATION OF PERSONAL INVESTMENT TOOLS FROM THE PERSPECTIVE OF DIGITAL FINANCE AND ITS INFLUENCE ON UKRAINIAN FINANCE MARKET
}

\author{
๑2021 MELNYK V. 0.
}

UDC 336.7

JEL: D53; E22; 016

\section{Melnyk V. O. Modification of Personal Investment Tools from the Perspective of Digital Finance and Its Influence on Ukrainian Finance Market}

Drastic changes in the financial services market under the influence of digitalization determine the relevance of research of the modern structure of this market, taking into account the emergence and development of the FinTech innovations. The increase in new investment instruments is attracting the attention of an increasing number of individual investors in the digital finance industry. Considering these tools, the preferences of individual investors require a separate study. The article is aimed at studying the financial market in digital finance and analyzing such types of investments as cryptocurrencies and crowdfunding, as well as the characterizing the online brokerage as a way to obtain investment services among individual investors. As a result of the study, the place and role of cryptocurrencies, crowdfunding and online brokerage in the investment activities of individuals is substantiated; the main mechanisms of work of these financial instruments are allocated and features of their development in Ukraine are characterized. The main disadvantages and advantages of crowdfunding and cryptocurrencies are defined and further steps are proposed regarding the prospects for their development in Ukraine. In addition, the article analyzes the current state of functioning of the online brokerage service in Ukraine and proves the relevance of the allocation of these financial instruments at the legislative level. Prospects for further research in this direction are the analysis of other digital instruments of personal investments, as well as a detailed study of the specifics of functioning of crowdfunding, cryptocurrencies and online brokerage in Ukraine. For the more efficient functioning of investment instruments in the sphere of digital finance, as well as effective use in practical activities, it becomes necessary to closer define these concepts at the legislative level and to substantiate the specifics of their work in detail.

Keywords: digital finance, individual investor, crowdfunding, cryptocurrencies, online brokerage.

DOI: https://doi.org/10.32983/2222-4459-2021-6-205-212

Fig.: 4. Bibl.: 22.

Melnyk Valeriia O. - Postgraduate Student of the Department of Finance, Taras Shevchenko National University of Kyiv (60 Volodymyrska Str., Kyiv, 01033, Ukraine)

E-mail: valeriamelnik3@gmail.com

УДК 336.7

JEL: D53; E22; 016

Мельник В. О. Модифікація інструментів персональних інвестицій в умовах диджитал-фінансів і їній вплив на фінансовий ринок України Кардинальні зміни на ринку фінансових послуг під впливом цифровізації визначають актуальність дослідження сучасної структури цього ринку з урахуванням появи та розвитку інновацій FinTесh. збільшення нових інвестиційних інструментів привертає увагу все більшої кількості окремих інвесторів галузі цифррових фінансів. Серед цих інструментів окремого дослідження потребують пресреренції індивідуальних інвесторів. Мета даної статті полягає в дослідженні фінансового ринку в умовах диджитал-фінансів та аналізі таких типів інвестицій, як криптовалюта та краудфандинг, а також характеристиці онлайн-брокериджу як способу отримання інвестиційних послуг серед індивідуальних інвесторів. у результаті дослідження було обгрунтовано місце та роль криптовалюти, краудфрандинга та онлайн-брокериджу в інвестиційній діяльності фрізичних осіб; виділено основні механізми роботи даних фінансових інструментів та охарактеризовано особливості їхнього розвитку в Україні. Визначено головні недоліки та переваги краудфрандингу та криптовалют і запропоновано подальші кроки щодо перспективи їхньгго розвитку в Україні. Окрім цього, у статті проаналізовано сучасний стан функціонування послуги онлайн-брокериджу в Україні та доведено актуальність виділення зазначених фінансових інструментів на законодавчому рівні. Перспективами подальших досліджень у даному напрямі є аналіз інших диджитал-інструментів персональних інвестицій, а також детальне вивчення специфіки функціонування краудфандингу, криптовалют та онлайн-брокериджу в Україні. задля більш ефективного функціонування інвестиційних інструментів у сфері диджитал-фінансів, а також результативного використання у практичній діяльності, постає необхідність в уточненні даних понять на законодавчому рівні та детальному обгрунтуванні специсіки ї роботи. Ключові слова: диджитал-фінанси, індивідуальний інвестор, краудфандинг, криптовалюти, онлайн-брокеридж.

Рис.: 4. Бібл.: 22.

Мельник Валерія Олексіївна - аспірантка кафедри фінансів, Київський національний університет імені Тараса Шевченка (вул. Володимирська, 60, Київ, 01033, Україна)

E-mail: valeriamelnik3@gmail.com

$\mathrm{N}$ owadays, customers in the financial sector are looking for intelligent and, at the same time, easy-to-use financial services, which could be used anywhere and anytime. Digital finance challenges the existing financial service providers and offers new opportunities for all investors.

Digital finance describes the digitalization of the financial industry, in general. It includes all electronic products and services of the financial sector, such as credit and chip cards, electronic exchange systems, home banking, and home trading services, as well as automated teller machines (ATMs). Moreover, all mobile and app services could be also involved in digital finance. While parts of the digital processes and services stated above are well-established (e. g., ATMs), there are other services and business models that are novel, not widely used, 
and are potentially meaningful for the financial industry. Such innovative services and business models that are based on new technologies are often referred to as 'FinTech' solutions [18, p. 539]. Fintech FinTech companies not only become an important component of the global and national economy, they but also transform the sector of financial services through innovative products, fundamentally changing the mechanism of the main traditional market participants. Individual investors, as being participants of the financial market, have also have changed their preferences, and expectations towards their behavior and, therefore, investment decisions. More and more individual investors are paying attention to the tools that are related to Internet technologies, because they are modern, progressive and accessible.

In this article, three main ways of investing concerning digital finance are going to be described. These are: crowdfunding, cryptocurrencies, which now are on their peak of development, and online brokerage. In its turn, cryptocurrencies and crowdfunding are considered as perspective investment tools for individual investors, whereas online brokerage is described as a way of investing money (Fig. 1). a professional participant in the securities market [16, p. 301]. According to the Law of Ukraine "On Securities and the Stock Market" of dated February 23, 2006 No. 3480-IV an investor who intends to buy or sell securities may not carry out these transactions independently [8]. To do this, he/she will need a broker (licensed securities trader and custodian) and a commercial bank (to open a current account).

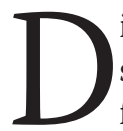
irect market access (DMA) is a similar type of service to Internet trading by definition, but different from a technological point of view [9]. This technology is used in Western and Asian developed stock exchanges and is a high-speed electronic channel ('gateway') of exchange information, which is usually used for trading in securities on foreign stock exchanges.

Connection to western Western stock exchanges requires fundamentally new technical solutions compared to the technologies which are used on domestic stock exchanges. Moreover, in Ukraine the mechanism of access to foreign financial markets is not regulated by law.

In the stock market, e-commerce became popular in the late twentieth century. Due to the development of Internet technologies, Internet brokerage has become a

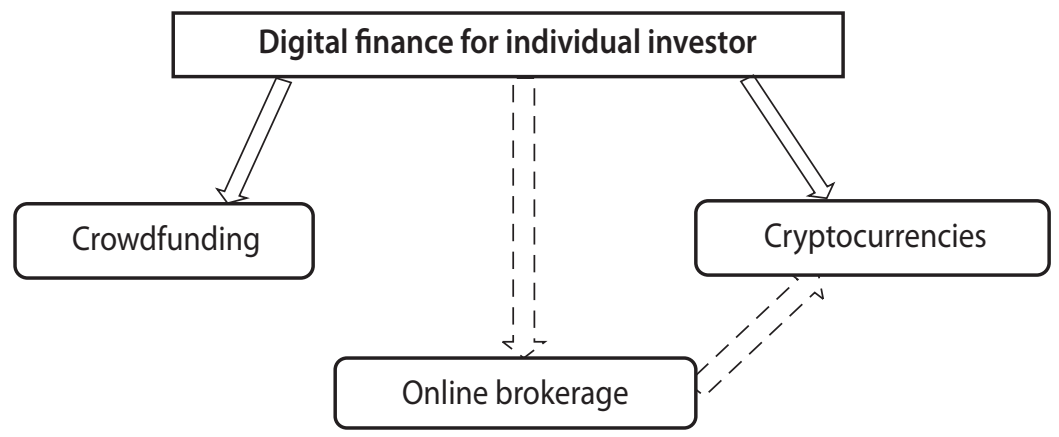

Fig. 1. Digital finance for individual investor

Source: created by the author.

From recent timeRecently, researches in the field of digital finance has been actively developing. Among the works in this area one should be noted the works of by such foreign economists as L. Gitman, R. Merton, Z. Bodie, K. Hamilton, R. Siegel, K. Yacht, R. Ekchebiev, V. Slepov, as well asand the works of by ukrainian Ukrainian economists: T. Kizyma, S. Yuriy, V. Fedosov, O. Shevchenko etc.

Methodology. During the research general scientific methods of cognition were used, such as: analysis and synthesis, method of scientific abstraction, logical, and historical methods, method of generalization and causal analysis, system and historical-economic approaches.

\section{Online brokerage}

Over the last decade, online brokerage service has become one of the innovations that has made life easier for the modern individual investor. This is a service provided not by the a stock exchange, but by a trader, i. e. - new service from brokers. Only As early as 20-25 years ago, an investor wishing to buy securities in the developed stock markets, an investor had to come directly to the a broker or contact him/her by phone. Thus, the time spent on the exchange transaction was at least $30 \mathrm{~min}$ utes, and the sources of information on the basis of which the investor had made decisions were the press, rumors or advice from the broker. However, with the advent and increasing integration of the World Wide Web into the economic processes, widespread popularity of the Internet trading services appeared and gained momentum in the securities market.

Internet technologies allow brokers to provide a fundamentally new set of services: data on online quotes, news and company reports, monitoring the client's investment portfolio (current value and return on assets), market research, in general and its individual segments, in particular, lending cash and stock assets to clients, the ability to work with derivative financial instruments, etc. 
Information interaction between the broker and clients is carried out via the Internet, which significantly increases the speed of setting and execution executingof the client's orders. Real operations of individuals on the stock exchange in real time appear, and the speed of execution executingof exchange orders and the available specialized information support are similar to those used by professional stock market participants [7].

There is no clear classification of Internet trading in the economic literature. According to foreign researchers, online brokerage can be divided into two types [5; $10 ; 11]$ :

1. "Mediatorial". This type of online trading is an electronic reflection of the real process of investing in securities. This type of Internet trading is characterized by the fact that the broker is the nominal holder of the client's securities. This gives him/her access to his their trading terminals connected to trading systems and exchanges. The broker's systems are accessed via the Internet, and the client can give orders for their exchange transactions in real time (Fig. 2).

In developed markets clients performe transactions and receive reports from brokers concerning registered transactions, and securities really change owners in the depository and clearing system between customer accounts brokers during small periods of time, which allows brokers to enter stock transactions for a short period of time, thus expanding the possibilities of exchange trade.

2. "Independent", or direct access to trading appeared later than "mediatorial" Internet trading. Direct access is a much more progressive and promising type of online trading for investors, but for most stock markets it is characterized by underdevelopment, high cost, the need for additional investment and legal irregularities (Fig. 3).
The main feature of the "independent" type of Internet trading is that the investor operates independently on the stock exchange in real time using special software without the direct mediation of an online broker. The investor must become a client of the broker, because the stock exchange cannot provide access to the an individual directly. However, such a broker must have or provide the client with a server located directly next to the servers of the exchange itself, the so-called 'colocation' [10]. Due to the closeness to the servers of the exchange, the investor will receive the benefits of this type of e-commerce: efficiency - the ability to not only perform the transaction, but also to immediately find the its parameters immediately, of the transaction if necessary; high performance, or the ability to perform many transactions in a short time. The last characteristic involves the use of mechanical and algorithmic trading systems in the trading process.

However, in terms of risks for the investor, the "independent" type of online trading carries great technical risks and contradicts the concept of optimal risk allocation, as it does not provide maximum protection of e-commerce components, whose proper functioning of which is most critical for the rational operation of the market as a whole. Under the conditions of direct access to trading via the Internet, the trading platform and its trading system become such a component. is the trading platform and its trading systemTherefore, the organization of DMA is not recommended for the exchange trading system via the Internet or other public telecommunications networks [10].

\section{Cryptocurrencies}

Online brokerage offers many opportunities and tools for the individual investor, including cryptocurrencies. Today, cryptocurrencies play a special role in

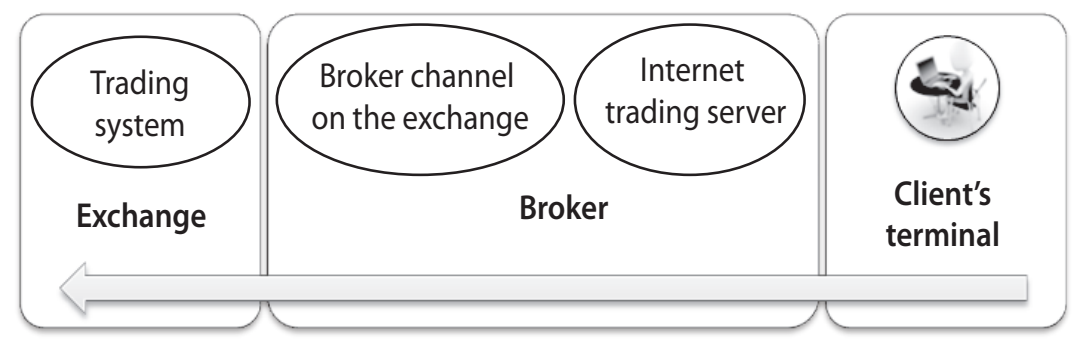

Fig. 2. “Mediatorial” type of online brokerage [16, p. 302-304]

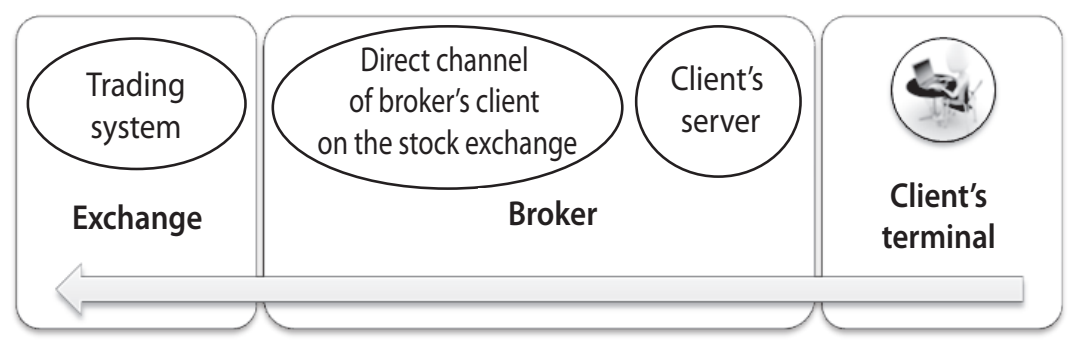

Fig. 3. "Independent", or direct type of online brokerage [16, p. 302-304] 
the portfolio of individual investors. Cryptocurrencies, despite their popularity only in a narrow circle, are gaining more and more weight in the economic environment, becoming one of the main assets of the future and an attractive object of investment. Investing in cryptocurrency has been become a successful project for many people. American businessmen Cameron and Tyler Winklevossi were the first to acquire the status of "Bitcoin billionaires" after their investment increased by 100 times in 2013 after buying $1 \%$ of all the Bitcoin [19].

$\mathrm{T}$ he European Central Bank, defines cryptocurrencies as a '...digital representation of value, not issued by a central bank, credit institution or emoney institution, which in some circumstances can be used as an alternative to money' [22]. CurrentlyNowadays, there are two main ways to invest into cryptocurrencies: direct investments over online exchanges and storing them in wallets, or indirect investments via structured retail products, which can be bought via existing brokerage accounts. The main characteristics of cryptocurrency include:

1) exchange for goods or services;

2) exchange for classic currency;

3) payment for goods and services;

4) the minimum level of impossibility of abduction;

5) payments, fast and direct transactions;

6) investment asset;

7) business development in cryptocurrency [6, p. 11-12].

There are about a thousand cryptocurrencies in the world, but the most famous one is bitcoin. A key breakthrough in bitcoin was that this technology allowed two people to exchange money without an intermediary, and to do so entirely in the digital form. Today, more than 100,000 organizations accept bitcoins for payment. Such companies include: Overstock.com, Virgin Galactic, Wordpress, PayPal (eBay), Tesla, Microsoft, Dell, AirBaltic, Air Lituanica, LOT, etc. Another option to use bitcoins is to buy gift cards in the following stores: Walmart, Amazon, Target and Nike [13, p. 45].

At the beginning of 2021 bitcoin exchange rate was about 29k USD per coin, at the beginning of May 2021 it reached $57 \mathrm{k}$ USD per coin, which one of the highest marks in the history of its existence. At the same time, during 2020 , there were several sharp setbacks in the cryptocurrency exchange rate, after which it resumed its rise to new records. According to Coinmarketcap.com, the capitalization of bitcoin as of May 5, 2021 is about \$ 2,.3 trillion. Since bitcoin and other cryptocurrencies cannot be classified as traditional financial assets, it is difficult to predict where their prices may go in the future [20].

Each cryptocurrency has its own capitalization ratio. The capitalization of a cryptocurrencies cryptocurrency depends on its total quantity and value per unit. The level of capitalization of a cryptocurrency is influenced by various factors, such as the volume of demand for it and the volume of supply of the currency. It should be mentioned that the demand for a cryptocurrency consists ofhas two types: transactional demand, which is due toreflects the need to buy a product for a particular currency, and investment demand. Today, the mechanism for calculating the market value of any cryptocurrency is quite incomplete, because the amount that is announced is very far from reality.

There isStill, a cryptocurrency market exists, and an investor who wants to invest in this area simply needs to keep track of its total value. Capitalization shows an important parameter that gives an understanding of what currency is worth or in which currency it is better to save keep your savings. Despite the limited issuance, the market value of cryptocurrency is programmed for sustainable economic development [12].

Supporters of the cryptocurrency market see an advantage in the new financial world that goes beyond the existing systems, preferring not to sell them it but to create savings. For others, cryptocurrency is a 'bubble' that can burst at any time, and this can happen, when cryptocurrencies are actively bought by retail investors [17].

As a result, there is still no consensus in the world on the further strategy for the development of cryptocurrency, its legalization and legality of use. However, most people remain interested in buying and using cryptocurrency. As long as the demand for e-currency exists, countries will continue to look for ways to regulate its circulation and use.

As for the predictions of its disappearance, this is, most likely, impossible, because a lot of effort, time and money were invested in its appearance and popularization. This is due to the fact that the main difference of e-currency is its decentralization and anonymity.

A ccording to the 2020 Geography of Cryptocurrency Report, which was prepared by Chainalysis, an American company, - Chainalysis, Ukraine was a leader in cryptocurrency investments by the volume of transactions and user activity [21]. However, attempts to regulate Ukrainian cryptocurrency market have not led to anything yet. The current Ukrainian legislation does not define this type of asset, does not classify it, doesand does not regulate the circulation, storage, possession, operations with the help of cryptocurrencies in Ukraine. A number of bills aimed at regulating the status of cryptocurrencies in Ukraine have been withdrawn.

Instead, the current tax legislation does not contain any special rules for taxation and declaration of such types of assets. This means, that the income of individuals from transactions with cryptocurrencies is taxed according to the general rules of the Ukrainian Tax CodexCode of Ukraine. The tax authorities in their individual tax consultations also note this.

The lack of legal regulation of cryptocurrency circulation in Ukraine does not creates special advantages neither for either taxpayers nor for the state. Such legal 
uncertainty can lead to many abuses and litigations in the future. On the one hand, according to the tax authorities, a person must pay taxes on income from the sale of cryptocurrency, ; on the other, - the same person is cannot be sure that (s)he will be able to protect his their ownership of the cryptocurrency in court.

To deal with this case Ukraine have has to create a strategy - the main regulators need to understand what exactly they want to achieve. It can be developed by involving large cryptocurrency players, possibly foreign investors, who have an idea of what such legislation should look like [14].

Based on the theoretical and practical analysis of the cryptocurrency market, the following trends in its further development can be highlighted:

1) the slow introduction of electronic money in all the spheres of society;

2) the ability to purchase more and more goods and services for cryptocurrency;

3) addition of the financial services market as a new payment instrument and type of investment assets, without replacing classic banking operations in the coming years;

4) reducing the level of anonymity when using cryptocurrency, which will be due to its greater popularization;

5) the spread of the legitimacy of cryptocurrency in most countries;

6) stabilization of the cryptocurrency rate in 5-10 years;

7) consolidation of Bitcoin positions as the main cryptocurrency and the emergence of new ones that will reach the scale of Bitcoin [6, p. 13-14].

\section{Crowdfunding}

Another innovative type of investment is crowdfunding, which is a special type of financing through fundraising for any project over the Internet, usually to produce creative products, such as creating a movie, book, music record album, computer game, etc usually creative products. The meaning of the concept of 'crowdfunding' concept was formed under the influence of microfinance concepts [4], but modern crowdfunding is its owna separate, unique category of fundraising.

There is a fundamental difference between crowdfunding and microfinance. In the case of microfinance, we are talkingspeak about funds meant to expand the a small business, which and it will not interest banks, firstly, due to, firstly, the small amount of funds that need to be attracted, and secondly, given the high risks and mostly lack of any guarantees. Microloans are usually taken by entrepreneurs who do not have enough funds to develop their small business.

In the case of crowdfunding, it is meant for more creative, subtle and innovative projects, which, however, require investment. Thus, the audiences of microfinance and crowdfunding organizations are completely differ- ent, and both are still quite uninteresting to for banks and other financial companies. However, in the near future, investment funds may become competitors of crowdfunding. This will happen, when investment crowdfunding reaches the peak of development, and entrepreneurs will be able to immediately turn to prospective buyers or private investors, avoiding the classic ways of raising funds in for new companies or just ideas that are developing dynamically. Experts suggest that in the future, banks will be able to create crowdfunding funds by themselves.

$\mathrm{T}$ Three agents take part in the crowdfunding process: developers, investors, and Internet platforms. For developers, the advantages of using this type of funding are low cost of capital and access to a large amount of information. For individual investors, there are several factors that may encourage them to invest through crowdfunding:

+ greater openness, and accessibility for understanding understandability, and use compared to other traditional financial options;

+ the ability possibility to invest small amounts in any project, and as a result, minor risks;

+ access to a new product before its official entry into the market;

+ opportunity to exchange thoughts, and ideas, as well as be part of innovative projects;

+ support of creative ideas [15].

Today, crowdfunding allows attracting financial resources of a large number of people (individual communities, different groups) through the Internet to implement various ideas and projects (mostly startups). The service is usually provided through specialized online platforms that help to create the most complete description of the a project or funding needs.

Briefly, the mechanism of crowdfunding can be represented as follows: a company or individual turns to a crowdfunding company with a certain idea. The crowdfunding company is testing tests the idea for legitimacy, relevance and feasibility and calculates all the possible risks. After approval of the idea is approved on the basis of the crowdfunding platform, a project is created and the amount to be collected for its implementation and the terms of its collection are announced [1, p. 55] (Fig. 4).

The reward that future investors can receive is also announced. The author of the project together with the crowdfunding company starts advertising the project through social networks, mass media, advertising and promotions, and various resources of the crowdfunding company. Investors are starting to invest in the project. At the same time, the minimum contribution can be, for example, $\$ 5$, which makes investing accessible to many segments of the population. The money is accumulated in the transit account of the crowdfunding company.

The global crowdfunding market is actively developing, especially since 2013. If in 2012 its volume amounted to 2.7 billion dollars, then the following year 


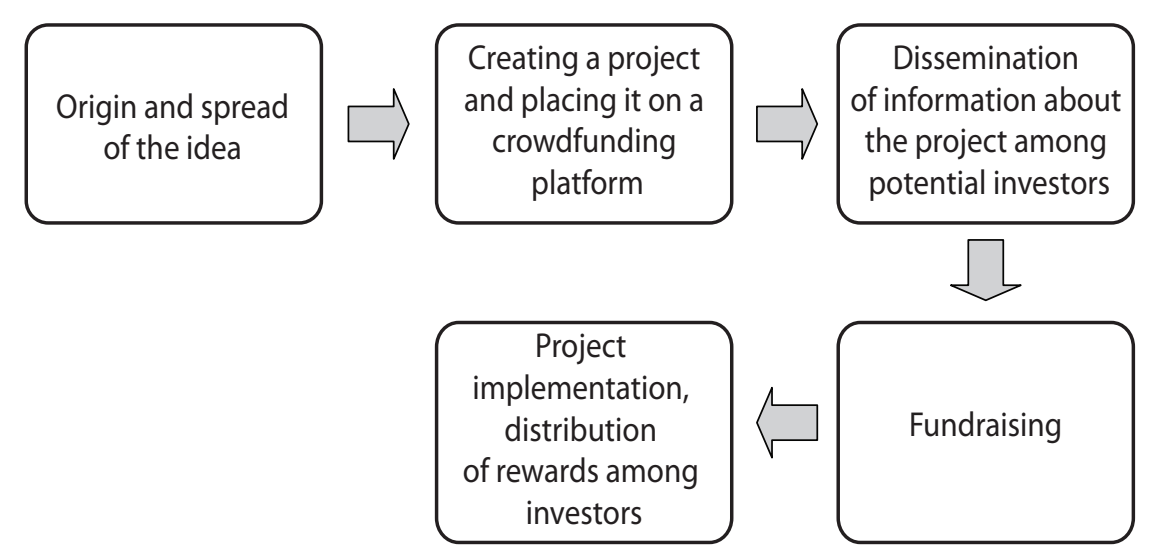

Fig. 4. Mechanism of crowdfunding

Source: compiled by the author based on [1].

it increased almost 2.3 times and reached the mark of 6.1 billion dollars [4, p. 38].

According to the World Bank, by 2025 the global volume of the crowdfunding market in the world will reach 96 billion dollars [17]. However, the general trend is that this will happen much sooner. In addition, according to the World Bank, only a third of crowdfunded projects are non-profit. This indicates that 'public investment' has indeed become an effective means of financing business projects, among which a significant share is occupied by innovative projects.

In Ukraine, the crowdfunding market is very poorly developed. Its resources are sufficient only to meet the small needs of small businesses and people. It is almost impossible to raise funds for the implementation of an ambitious high-tech project, a startup with a product that will be focused on the Western or Asian market, but made on Ukrainian platforms. So, such projects have to use the services of European and American crowdfunding companies. Nevertheless, at the same time domestic entrepreneurs are face facing a number of difficulties, which can be divided into territorial, organizational and cultural ones. The first one, for example, is that most crowdfunding companies work only with entrepreneurs from Western Europe, North America and Australia. Others require to open an account with certain American or European banks. Among the world-famous companies, only "Kickstarter" and "Indiegogo" work with users from almost all over the world. This, in some way, limits the Ukrainian user's ability to choose a platform and region of the world to raise funds.

The most popular crowdfunding platforms in Ukraine are "Spilnokosht" (2012), "Na starti" (2014) and "Kub" (2016). In particular, thanks to the "Spilnokosht", dozens of projects have already raised money for startups, environmental and public events, work of the media, organization of festivals and performances, shooting videos [2].

Today, the crowdfunding market is the most promising in the field of information technology, so the a Ukrainian public funding platform can be the first step towards stabilizing the economy and, in the future, for the effective development of our country and reaching the samea position, equal position with to that of the world leaders.

The positive results of the crowdfunding development of crowdfunding in Ukraine is that it has a predominantly social orientation. Thus, it contributes to the formation of investment traditions, the implementation of social and economic innovations, and the emergence of alternative bank financing. Foreign experience demonstrates the effectiveness of such a social model, so it is important to consider help Ukraine to ensure economic growth and reduce dependence on borrowed resources.

\section{CONCLUSIONS}

FinTech is a significant value for the expansion of financial services and products in new areas and among different segments of the population. Due to the large percentage of people who are outside the banking system or receive insufficient services, as well as the difficulties for banks to serve provide service for micro- and small enterprises and people living in remote areas, there is an unfilled financial niche in the market. This creates significant investment opportunities for the FinTech sector.

As a result, the development of digital finance opens up a completely different range of opportunities and prospects for individual investors. Unfortunately, Ukraine does not currently have the most favorable climate for receiving all the benefits of digital investment instruments. The main problem that hinders the development of the FinTech industry is unstable economic situation in the country. As there are certain imbalances in the economy in Ukraine, the risk ofthreat for sustainable development of the FinTech industry is increasing. It is becoming increasingly difficult for investors to trust their own funds, as the shadow economy and the devaluation of the national currency remain high.

As a solution, foreign capital could accelerate the development of technology, which will improve the economic condition ofsituation in the country, as attracting foreign investment will make a significant contribution to 
improving the FinTech industry. Currently, foreign investors are interested in certain areas of FinTech, including:

+ electronic wallets;

+ online payment systems;

+ blockchain modernization;

+ contactless payments [3, pp. 482].

Moreover, the experience of leading advanced countries can accelerate the process of attracting new innovative investment instruments tools to the Ukrainian financial market.

\section{LITERATURE}

1. Абакуменко О. В. Краудфандинг як інструмент фінансування інноваційно-технологічних проектів. Чернігівський науковий часопис. 2016. № 1. С. 52-60.

2. В Украине появился онлайн проект взаимного финансирования «СімЗірок» // AIN.UA. 12.11.2013. URL: http://ain.ua/2013/11/12/501441

3. В'язовий С. М., Пасічник І. В. Розвиток fintechіндустрії в Україні та їі ризики для банківської діяльності. Східна Європа: економіка, бізнес та управління. 2019. Вип. 4. С. 480-484. URL: http://www. easterneurope-ebm.in.ua/journal/21_2019/74.pdf

4. Васильєв О. В., Матющенко С. С. Краудфандинг - сучасний інструмент фінансування розвитку інтелектуального капіталу. Інвестиції: практика та досвід. 2016. № 18. C. 36-40. URL: http://www.investplan. com.ua/pdf/18_2016/8.pdf

5. Ковальова В. Грошові фонди витісняють депозити? // finance.ua. 20.04.2011. URL: https://news.finance. ua/ua/news/-/235687/groshovi-fondy-vytisnyayutdepozyty

6. Криптовалюта:стантатенденціїрозвитку/Двуліт3.П., Передало Х. С., Тиліпська Р. Б., Терно Р. М., Стибель Р. І. Економіка та держава. 2019. № 1. С. 10-14. DOI: $10.32702 / 23066806.2019 .1 .10$

7. Екшембиев Р. С. Персональные финансы в финанн совой системе государства : монография. М. : Магистр, 2008. 302 с.

8. Закон України «Про цінні папери та фондовий ринок» від 23.02.2006 р. № 3480-IV. URL: https://zakon. help/law/3480-IV/

9. Інтернет-трейдинг // ПАТ «Українська біржа». URL: http://www.ux.ua/a1769

10. Інформація про торги // ПАТ «Українська біржа»: URL: http://www.ux.ua/a1769. - Назва з екрана.

11. Красножон С. В. Інвестиційна діяльність індивідуальних інвесторів // Перспективные инновации в науке, образовании, производстве и транспорте : сб. тезисов междунар. науч.-практ. конф. Одеса, 2009. C. 98-100. URL: http://ena.lp.edu.ua:8080/ bitstream/ntb/6491/1/36.pdf

12. Маковоз О. С., Передерій Т. С. Капіталізація інвестицій у криптовалюту // Нові форми грошей та фінансових активів: становлення, перспективи, ризики : тези I Міжнародної науково-практичної конференції (м. Київ, 29 листопада 2017 р.). Київ : КНЕУ, 2017. C. 59-63.

13. Сохацька О., Курант Т. Криптовалюти: засіб платежу чи інвестиційний інструмент? // Перші наукові читання пам'яті С. І. Юрія. Тернопіль, 2015.
C. 42-47. URL: http://dspace.wunu.edu.ua/bite stream/316497/12951/1/Сохацька.pdf

14. Родін Р. Чому Україна легалізує криптовалюту не 3 того кінця // Економічна правда. 26.01.2021. URL: https://www.epravda.com.ua/cola umns/2021/01/26/670382/

15. Шевченко О. М., Казак О. О. Розвиток краудфандингу в умовах цифрової трансформації економіки України. Ефективна економіка. 2019. № 3. DOI: 10.32702/2307-2105-2019.3.43

16. Щербина А. Г. Тенденції розвитку електронної торгівлі на фондовому ринку. Актуальні проблеми економіки. 2012. № 2. С. 301-309.

17. Crowdfunding Statistics // Fundly. URL: https://blog fundly.com/crowdfunding-statistics

18. Gomber P., Koch J.-A., Siering M. Digital Finance and FinTech: current research and future research directions. Journal of Business Economics. 2017. Vol. 87. P. 537-580. DOI: https://doi.org/10.1007/s11573-017-0852-x

19. How Winklevoss twins used $\$ 11 \mathrm{~m}$ Facebook payout to become world's first Bitcoin billionaires // The Daily Telegraph. 2017. URL: https://www.telegraph.co.uk/ technology/2017/12/02/winklevoss-twins-becomefirst-bitcoin-billionaires/

20. Polyviou A., Velanas P., Soldatos J. Blockchain Technology: Financial Sector Applications Beyond Cryptocurrencies // Proceedings of The $3^{\text {rd }}$ Annual Decentralized Conference on Blockchain and Cryptocurrency. 2019. Vol. 28. Is. 1. P. 1-5.

DOI: https://doi.org/10.3390/proceedings2019028007

21. The 2020 Global Crypto Adoption Index: Cryptocurrency is a Global Phenomenon // Chainalysis. URL: https://blog.chainalysis.com/reports/2020-globalcryptocurrency-adoption-index-2020

22. Virtual Currency Schemes. October 2012 / European Central Bank. URL: https://www.ecb.europa.eu/pub/ pdf/other/virtualcurrencyschemes201210en.pdf

Scientific Supervisor - Liutyi I. O., D. Sc. (Economics), Professor, Head of the Department of Finance, Taras Shevchenko National University of Kyiv

\section{REFERENCES}

Abakumenko, O. V. "Kraudfandynh yak instrument finansuvannia innovatsiino-tekhnolohichnykh proektiv" [Crowdfunding as a Tool for Financing Innovation and Technological Projects]. Chernihivskyi naukovyi chasopys, no. 1 (2016): 52-60.

"Crowdfunding Statistics". Fundly. https://blog.fundly. com/crowdfunding-statistics

Dvulit, Z. P. et al. "Kryptovaliuta: stan ta tendentsii rozvytku" [Cryptocurrency: State and Trends of Development]. Ekonomika ta derzhava, no. 1 (2019): 10-14. DOI: 10.32702/23066806.2019.1.10

Gomber, P., Koch, J.-A., and Siering, M. "Digital Finance and FinTech: current research and future research directions". Journal of Business Economics, vol. 87 (2017): 537-580.

DOI: https://doi.org/10.1007/s11573-017-0852-x

"How Winklevoss twins used $\$ 11 \mathrm{~m}$ Facebook payout to become world's first Bitcoin billionaires". The Daily 
Telegraph. 2017. https://www.telegraph.co.uk/technology/2017/12/02/winklevoss-twins-become-firstbitcoin-billionaires/

"Informatsiia pro torhy" [Bidding Information]. PAT «Ukrainska birzha». http://www.ux.ua/a1769

"Internet-treidynh" [Internet Trading]. PAT «Ukrainska birzha». http://www.ux.ua/a1769

Kovalyova, V. "Hroshovi fondy vytisniaiut depozyty?" [Monetary Funds Displace Deposits?]. finance.ua. April 20, 2011. https://news.finance.ua/ua/news/-/235687/ groshovi-fondy-vytisnyayut-depozyty

Krasnozhon, S. V."Investytsiina diialnist indyvidualnykh investoriv" [Investment Activity of Individual Investors]. Perspektivnyye innovatsii v nauke, obrazovanii, proizvodstve i transporte. 2009. http://ena.Ip.edu.ua:8080/ bitstream/ntb/6491/1/36.pdf

[Legal Act of Ukraine] (2006). https://zakon.help/law/3480-IV/

Makovoz, O. S., and Perederii, T. S. "Kapitalizatsiia investytsii u kryptovaliutu" [Capitalization of Investments in Cryptocurrency]. Novi formy hroshei ta finansovykh aktyviv: stanovlennia, perspektyvy, ryzyky. Kyiv: KNEU, 2017. 59-63.

Polyviou, A., Velanas, P., and Soldatos, J. "Blockchain Technology: Financial Sector Applications Beyond Cryptocurrencies". Proceedings of The $3^{\text {rd }}$ Annual Decentralized Conference on Blockchain and Cryptocurrency, vol. 28, no. 1 (2019): 1-5.

DOI: https://doi.org/10.3390/proceedings2019028007

Rodin, R. "Chomu Ukraina lehalizuie kryptovaliutu ne z toho kintsia" [Why Ukraine Legalizes Cryptocurrency from the Wrong End]. Ekonomichna pravda. January 26, 2021. https://www.epravda.com.ua/columns/2021/01/26/670382/

Shcherbyna, A. H. "Tendentsii rozvytku elektronnoi torhivli na fondovomu rynku" [Development Trends of Electronic Trade at Stock Market]. Aktualni problemy ekonomiky, no. 2 (2012): 301-309.
Shevchenko, O. M., and Kazak, O. O. "Rozvytok kraudfandynhu $v$ umovakh tsyfrovoi transformatsii ekonomiky Ukrainy" [Crowdfunding Development in the Conditions of Digital Transformation of Ukraine's Economy]. Efektyvna ekonomika, no. 3 (2019). DOI: 10.32702/2307-2105-2019.3.43

Sokhatska, O., and Kurant, T. "Kryptovaliuty: zasib platezhu chy investytsiinyi instrument?" [Cryptocurrencies: A Means of Payment or an Investment Instrument?]. Pershi naukovi chytannia pamiati S. I. Yuriia. Ternopil, 2015. http://dspace.wunu.edu.ua/bitstream/316497/12951/1/Сохацька.pdf

"The 2020 Global Crypto Adoption Index: Cryptocurrency is a Global Phenomenon". Chainalysis. https://blog. chainalysis.com/reports/2020-global-cryptocurrencyadoption-index-2020

"V Ukraine poyavylsya onlayn proekt vzaimnogo finansirovaniya "SimZirok»" [An Online Project of Mutual Financing "SimZirok" Has Appeared in Ukraine]. AIN.UA. November 12, 2013. http://ain.ua/2013/11/12/50144

"Virtual Currency Schemes. October 2012". European Central Bank. https://www.ecb.europa.eu/pub/pdf/other/ virtualcurrencyschemes201210en.pdf

Vasyliev, O. V., and Matiushchenko, S. S. "Kraudfandynh -suchasnyi instrument finansuvannia rozvytku intelektualnoho kapitalu" [Crowdfunding - A Modern Financing Instrument for Development of the Intellectual Capital]. Investytsii: praktyka ta dosvid, no. 18 (2016): 36-40. http://www.investplan.com.ua/pdf/18_2016/8.pdf

Viazovyi, S. M., and Pasichnyk, I. V. "Rozvytok fintech-industrii v Ukraini ta yii ryzyky dlia bankivskoi diialnosti" [The Development of the Fintech Industry in Ukraine and its Risks for Banking]. Skhidna Yevropa: ekonomika, biznes ta upravlinnia, is. 4 (2019): 480-484. http://www. easterneurope-ebm.in.ua/journal/21_2019/74.pdf

Yekshembiyev, R. S. Personalnyye finansy $v$ finansovoy sisteme gosudarstva [Personal Finance in the Financial System of the State]. Moscow: Magistr, 2008. 